\title{
DELEGAÇÃO DE PODERES
}

\author{
Carios de Britto Pereira \\ Professor da Faculdade de Direito da \\ Universidade do Paraná.
}

1. Embora dispusesse o ante-projeto da lei das sociedades por ações (art. 117) que seriam elas administradas por dois ou mais diretores, foi a disposição corrigida, na revisão, para ficar constando, no art. 116, que "a sociedade anônima ou companhia será administrada por um ou mais diretores..."

Alterou-se, então, a norma que já vinha da lei revogada, para se admitir a possibilidade de ser a administração da sociedade confiada a uma só pessôa.

Concentrados os poderes da Diretoria em uma pessôa única, esta há-de exercê-los em tôda a sua plenitude, podendo tão sómente, no limite deles e de suas atribuições, "constituir, em nome da sociedade, mandatários ou procuradores, especificados no instrumento os atos e operações que poderão praticar" (Art. 116, § $5 .^{\circ}$ ).

2. Estabelecendo, porém, os estatutos sociais, que a emprêsa será administrada por dois ou mais diretores, dos mesmos deverão constar "as atribuições de cada diretor e os poderes em que são investidos" (art. 116, § 1. ${ }^{\circ}$, letra e). Cada diretor tem sua função determinada na sociedade e o encargo de certos atos sociais. Sómente no silêncio dêles, competirão a qualquer diretor a representação ativa e passiva da sociedade e a prática dos atos necessários ao funcionamento regular da sociedade (art. 116, $\S 2 .^{\circ}$ ). 
Distribuida, assim, entre vários diretores a administração social, com atribuições e poderes, definidos nos estatutos, será lícito a um diretor delegar algum ou alguns dos seus poderes a outro diretor, para praticá-los na sua ausência ou impedimento?

3. A Junta Comercial do Estado de São Paulo indeferiu, há pouco tempo, o arquivamento de uma dessas delegações, outorgada pelo diretor de uma sociedade anônima a outro diretor. Serviu de fundamento para a decisão da Junta o parecer do seu Proeurador, que entendeu não ser lícito a um diretor delegar ou atribuir algum ou alguns de seus poderes a outro diretor, porque, em face do art. $116, \S 5 .^{\circ}$, do Decreto-lei $n .^{\circ} 2627$, de 26 de setembro de 1940 (Lei de sociedades por ações), "as atribuições e poderes conferidos pela lei aos diretores de uma sociedade anônima não podem ser outorgados a outro órgão, criado pela lei ou pelos estatutos".

Merece, todavia, reparo a decisão, que não tem apôio legal. A lei não proibe essa delegação. Diz tão sómente o seguinte:

"Art. 116 ...

$\S 5 .^{\circ}$ - As atribuições e poderes, conferidos pela lei aos diretores, não podem ser outorgados a outro orgão, criado pela lei ou pelos estatutos".

O que a lei preceitua, no dispositivo citado, é sómente que as atribuições e poderes por ela conferidos aos membros da Diretoria não podem ser outorgados a outro orgão, criado pela lei ou pelos estatutos.

São orgãos da sociedade, criados pela lei, a Assembléia Geral, a Diretoria e o Conselho Fiscal. É orgão criado pelos estatutos o Conselho Consultivo. A êsses orgãos - Assembléia Geral, Conselho Fiscal, Conselho Consultivo - com funções determinadas na sociedade, funções diversas da administração, é que proibe a lei a outorga de poderes dos diretores.

Não podem ser outorgados poderes a outro orgão, diz a lei. Mas o diretor de uma sociedade, a quem outro diretor delega ou atribue algum ou alguns de seus poderes, não é evidentemente outro orgão, não é um terceiro estranho à sociedade, nem 
é nomeado pelo diretor delegante. Faz parte da Diretoria, pertence ao mesmo orgão, integra a administração da sociedade. Não proibe a lei, portanto, que a êste companheiro de administração lhe delegue outro diretor algum ou alguns dos poderes que lhe são conferidos nos estatutos.

A delegação de poderes de um diretor a outro não ofende, pois, a lei das sociedades anônimas.

4. A matéria é da alçada exclusiva dos estatutos. A delegação de poderes de um diretor a outro pode ser legalmente feita, a menos que os estatutos o proibam, ou restrinjam êsse direito.

Entre as restrições que os estatutos podem instituir está justamente esta, como ensina ALOYSIO LOPES PONTES:

"Entre as restrições que os estatutos podem estabelecer inclue-se a de vedar aos diretores deleguem seus poderes, isto é, que instituam representantes com alguns de seus poderes, o que se justifica pelo fato de constituir a delegação de funçốes uma faculdade, não uma obrigação..."

Assim sendo, podem os estatutos proibir tal delegação sem que por isso sejam impugnáveis".

(ALOYSIO LOPES PONTES - Sociedades Anônimas $2 .^{a}$ edição, n. ${ }^{\circ} 439$, pág. 405 ).

Quer dizer, não restringindo os estatutos êsse direito, pode haver a delegação de poderes de um diretor a outro.

5. Cumpre ao Registro do Comércio o exame do ato constitutivo da sociedade anônima, para lhe negar o arquivamento, se não foram observadas as prescrições legais, bem como se nele figuram cláusulas contrárias à lei, ordem pública ou aos bons costumes (art. 53).

Arquivado o ato constitutivo ou, posteriormente, a reforma dos estatutos de uma sociedade anônima, já não pode o Registro do Comércio se opôr a nenhuma decisão ou a nenhum ato tomado por qualquer dos orgãos sociais, em consonância com as disposições estatutárias. 
Assim, se os estatutos autorizam expressamente a delegação e se o Registro do Comércio arquivou êsses estatutos já não lhe é possível deixar de admití-la, não lhe é lícito impugnar o ato da delegação.

Entre diretores, por conseguinte, a outorga de atribuições e poderes de um a outro, se permitida nos estatutos, é lícita e deve ser reconhecida para o devido arquivamento do ato no Registro do Comércio. 